\title{
KARBANTARTÁSI SZOLGÁLTATÁSOK VIZSGÁLATA AZ AGRÁRIUMBAN
}

\section{ANALYSIS OF MAINTENANCE SERVICES IN AGRICULTURE}

\author{
Oláh Béla \\ Szervezéstudományi és Logisztikai Tanszék, GAMF Mủszaki és Informatikai Kar, Neumann János Egyetem, \\ Magyarország \\ https://doi.org/10.47833/2020.2.AGR.004
}

\section{Kulcsszavak: \\ üzemfenntartás \\ szolgáltatás \\ agrárvállalkozások \\ felmérés}

\section{Keywords:}

maintenance

service

agricultural companies

survey

\section{Cikktörténet:}

Beérkezett 2019. október 30. Átdolgozva 2020. február 24. Elfogadva 2020. március 2.

\begin{abstract}
Összefoglalás
Napjainkban a karbantartás egyre nagyobb fontossággal bír, mégis sajnálatos módon igen kevés az információ a hazai karbantartási szolgáltatások helyzetéröl kiváltképp a mezőgazdaságban. A szerző kérdőíves kutatást végzett Magyarország keleti térségében müködő kis- és közepes méretü agrárvállalkozások körében. A tudományos munka e felmérésröl és annak kiértékeléséröl, különös tekintettel a gépfenntartási szolgáltatások igénybevételéről, kínálatáról ad számot, valamint összehasonlítja ezen megállapításokat a mezőtúri Tessedik Sámuel Főiskola Mezőgazdasági Főiskolai Kar Karbantartás Tanszékének munkatársai által készített korábbi vizsgálat eredményeivel [1, 13, 14, 15].
\end{abstract}

Abstract
Maintenance is gaining more and more importance nowadays;
in spite of this fact it is regrettable that sufficient information is
hardly available on the state of the domestic maintenance
services particularly in agriculture. The author carried out the
survey by means of a questionnaire within the sphere of the
small- and medium-scale agricultural companies operating in
the eastern region of Hungary. The scientific research gives an
account of this survey and the experiences of its evaluation,
especially of the utilization and supply of the maintenance
services as well as compares these assessments with results of
earlier projects carried out by colleagues of the Department of
Maintenance at the Agricultural College Faculty of Tessedik
Sámuel College in Mezötúr [1,13,14,15].

\section{Bevezetés}

A gépek, berendezések meghibásodását - a funkcióképességük elvesztését - mégoly korszerü, megelőző jellegű karbantartási stratégiák és módszerek alkalmazásával sem lehet teljes egészében kizárni. Zavarok, állásidők előfordulnak, ezek nem ritkán hatalmas veszteségeket okoznak [1, 13]. Nem véletlen tehát, hogy a karbantartás fontossága növekszik. A müszakigazdasági fejlődés a karbantartás és a karbantartási szolgáltatások fejlesztését is igényli [12].

\footnotetext{
* Tel.: +36 204954951

E-mail cím: olah.bela@gamf.uni-neumann.hu
} 
Szolgáltatásnak nevezünk minden olyan tevékenységet, amelyet más vállalat, intézmény, szervezet végez az üzem számára, illetve megfordítva, az üzem végez valamilyen ellenértékért másoknak [2].

Egyre inkább elfogadott felfogás szerint a karbantartás is produktív tevékenység olyan értelemben, hogy a gépek, berendezések funkcióellátásához szükséges és a használat során óhatatlanul egyre fogyó készletet - az ún. elhasználódási tartalékot (EHT) - biztosítja (megóvja, ismételten helyreállítja, ellenőrzi) a termelés számára [7].

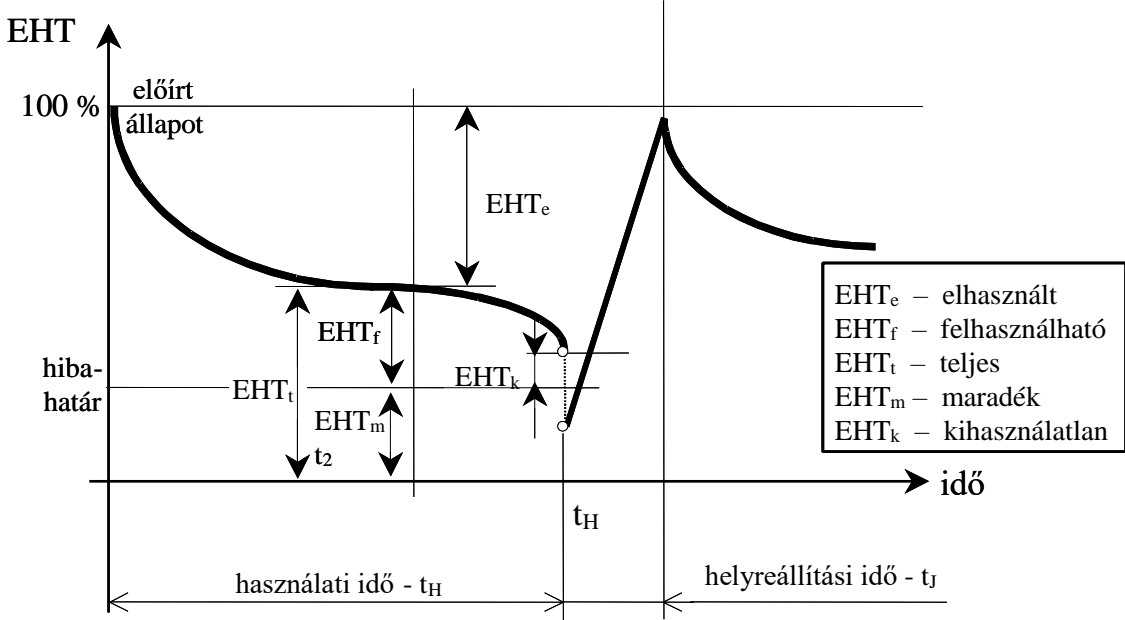

1. ábra. Az elhasználódási tartalék alakulása a használati idő függvényében [20]

Az EHT jelenti a gép használati értékét az üzemeltető számára [2]. Az EHT változását az 1. ábra mutatja.

A szükséges karbantartási feladatokat belső vagy külső szolgáltató végezheti. A belső szolgáltató a cég saját karbantartó szervezete, a külső pedig általában rendszeresen vagy eseti jelleggel szolgáltatásait kínáló szakszolgáltató, szakszerviz, vagy más cég karbantartási szervezete. Az igénylő adott esetben mérlegelheti a saját vagy a külső kapacitás igénybevételét [12]. A karbantartási tevékenységek kiszervezése (outsourcing) az utóbbi évtizedek tendenciája szerint egyre bővül [7].

A karbantartás is tehát alapvetően szolgáltatás jellegű tevékenység egy termelő szervezet szempontjából, akár belső (saját) erőforrásokkal, akár külső (idegen) szervezettel végeztetjük. $A$ karbantartási feladatok megvalósításának három megoldási módja:

- saját erőforrással végezhető karbantartási feladatok;

- külső karbantartó szolgáltatás igénybevétele;

- szolgáltatás nyújtható más üzem részére, ha azt a karbantartási erőforrások, meglevő kapacitások (időszakosan vagy rendszeresen) lehetővé teszik.

Ez utóbbi megoldás természetesen gazdaságilag kedvező, hiszen

- elősegíti a kapacitások kihasználását;

- javítja a karbantartás hatékonyságát;

- hasznosítható kapcsolatrendszert müködtet;

- hozzájárulhat a karbantartás fejlesztéséhez [15, 9, 10].

A karbantartási szolgáltatások helyzetéröl alig jelenik meg hazai közlemény, különösen igaz ez a mezőgazdasági üzemekre, ezért a szerző ezt kívánta megvizsgálni Magyarország keleti térségében, elsősorban az Alföldön.

\section{Módszer}

A lehetőségek keretein belül több mint 40 üzemet magába foglaló személyes interjú keretében kitöltött kérdőíves helyszíni felmérés - amibe a szakmai gyakorlatukat töltő mezőgazdasági és élelmiszeripari gépészmérnök, illetve müszaki menedzser gépüzemfenntartó 
szakirányos hallgatók is bevonásra kerültek - elvégzése mellett döntött a szerző. A kérdések a cég adataira; a karbantartás egészére és szolgáltatási helyzetére, a gépjavítás egyes területeire és a jövőbeli - szolgáltatásokkal kapcsolatos - terveire irányultak.

A dolgozat célkitűzésének megvalósítása érdekében a szerző kiértékelte a fenntartás helyzetének megítélésére készített kérdőíves felmérés [4] gépfenntartási szolgáltatásokat érintő részeit (gépfenntartási tevékenységek, igénybevett és nyújtott gépfenntartási szolgáltatások, azok tervezett fejlesztése), szembe/párhuzamba állította a családi gazdaságokra vonatkozó adatokat, arányokat a társas vállalkozásokéval és megállapításait összehasonlította az FVM 43532. sz. K+F téma és az NKA-K-2/2002. számú kutatási téma keretében végzett korábbi kutatások [14, 15, 1 , 13] eredményeivel is.

\section{Eredmények}

\subsection{A válaszoló cégek néhány jellemzője}

A mezőgazdasági működési területű egyéni és társas vállalkozások körében személyes interjú során elvégzett kérdőíves felmérés (melynek egy részletét mutatja a 2. ábra) feldolgozásával a karbantartási szolgáltatások helyzetéről is információkhoz jutott a szerző.

3. Milyen elven müködik a gépfenntartási rendszer?

\begin{tabular}{|c|c|c|c|c|c|c|c|}
\hline$\square$ & csak hibaelhárítás & $\square$ & $\begin{array}{l}\text { alapvetôen ciklikus- } \\
\text { periodikus karbantartás }\end{array}$ & $\square$ & $\begin{array}{l}\text { alapvetôen állapot- } \\
\text { függô karbantartás }\end{array}$ & $\square$ & vegyes \\
\hline$\square$ & nincsen rendszer & $\square$ & is éspedig & & & & \\
\hline
\end{tabular}

4. Vesz-e igénybe gépfenntartási szolgáltatásokat? $\quad \square$ igen $\quad \square$ nem

Ha igen, Milyen okból?

\begin{tabular}{|c|c|c|c|c|c|c|c|c|c|c|}
\hline$\square$ & $\begin{array}{l}\text { nincs saját kapaci- } \\
\text { tás }\end{array}$ & $\square$ & nincs eszköz & $\square$ & \multicolumn{3}{|c|}{$\begin{array}{l}\text { nem elegendô a szak- } \\
\text { mai felkészültség }\end{array}$} & \multicolumn{3}{|c|}{$\begin{array}{l}\text { kötelezö (pl. hatósági } \\
\text { jellegü, garancia, stb.) }\end{array}$} \\
\hline$\square$ & \multicolumn{2}{|c|}{ gazdaságilag kedvezőbb } & \multicolumn{8}{|c|}{$\square$ más, éspedig: } \\
\hline \multicolumn{11}{|c|}{ Milyen szakterületen? } \\
\hline$\square$ & $\begin{array}{l}\text { karbantartási rend- } \\
\text { szer kialakitása }\end{array}$ & $\square$ & $\begin{array}{l}\text { váratlan hibaelhá- } \\
\text { rítás }\end{array}$ & & $\square \begin{array}{l}\text { müszaki di- } \\
\text { agnosztika }\end{array}$ & $\square$ & \multicolumn{2}{|c|}{ nagyjavítás } & $\square$ & $\begin{array}{l}\text { garanciális } \\
\text { müveletek }\end{array}$ \\
\hline$\square$ & speciális javítások & $\square$ & \multicolumn{2}{|l|}{$\begin{array}{l}\text { mûszaki elökészí- } \\
\text { tés, tervezés }\end{array}$} & $\square$ beüzemelés & $\square$ & \multicolumn{4}{|c|}{ más, éspedig: ................................ } \\
\hline \multicolumn{11}{|c|}{ Ezek jelentôsége a vállalkozás/cég egésze szempontjából? } \\
\hline$\square$ & kiemeltek & $\square$ & \multicolumn{2}{|c|}{ jelentösek } & \multicolumn{3}{|l|}{$\square$ számottevök } & \multicolumn{3}{|c|}{$\square$ jelentéktelenek } \\
\hline
\end{tabular}

5. Végez-e gépfenntartási szolgáltatásokat más cégeknek, magán személyeknek? $\square$ igen $\square$ nem Ha igen, Milyen céllal?

\begin{tabular}{|c|c|c|c|c|c|c|c|c|c|}
\hline$\square$ & $\begin{array}{l}\text { speciális szakis- } \\
\text { meret hasznosítása }\end{array}$ & & $\begin{array}{l}\text { kapacitás- } \\
\text { kihasználás }\end{array}$ & $\square$ & $\begin{array}{lr}\text { kialakult } r & \text { tartós } \\
\text { partneri kapcsolat }\end{array}$ & $\square$ & $\begin{array}{l}\text { kijelölt szol- } \\
\text { gáltatóként }\end{array}$ & $\square$ & $\begin{array}{l}\text { elsôsorban gaz- } \\
\text { dasági okokból }\end{array}$ \\
\hline
\end{tabular}

\section{2. ábra. Kérdőív részlet}

Jelen kiértékelésbe 36 mezőgazdasági vállalkozás szerepelt, melyek mindegyike kivétel nélkül a keleti országrészben müködik [4]. A gazdaságok 25\%-a őstermelő (9 db), 30,6\%-a családi (11 db), 44,4\%-a pedig (16 db) társas vállalkozás - 7 Zrt., 6 Kft. és 3 szövetkezet - volt. 18 gazdaság (50\%) tisztán növénytermesztéssel, $13(36,1 \%)$ állattenyésztéssel is foglalkozik. Bevonásra került még 2 művelt terület nélküli szolgáltató és 3 több tízezer hektáron termeltető termelö üzem is ebbe a vizsgálatba. A müvelt (saját+bérelt) földterület $(7 \div 9.500 \mathrm{ha})$ átlagosan 1.077 ha. Az őstermelőknél ez az érték 28 ha $(8 \div 59$ ha), a családi gazdálkodóknál 130 ha $(7 \div 357$ ha), míg a társas vállalkozások esetén 2.883 ha. A foglalkoztatottak száma 21 (58,3\%) esetben 10 fő alatti, az egyéni gazdaságok kivétel nélkül mind ilyenek.

A kérdőívet kitöltők közül $26(72,2 \%)$ gazdaság vesz igénybe külső cégtől fenntartási szolgáltatásokat. Gazdálkodási forma szerint nem tapasztalni különbséget: az egyéni vállalkozások 70\%-a (14 db), míg a társaságok 75\%-a (12 db) vallott így. Ezen arányok megegyeznek a tíz esztendővel korábbi értékekkel $[15,9,10]$. Saját megítélésük szerint az általuk 
igénybevett szolgáltatásokat 7,7\%-uk kiemeltnek, 38,5\%-uk jelentősnek, 38,5\%-uk számottevőnek, 15,4\%-uk pedig jelentéktelennek [16] értékelte (3. ábra).

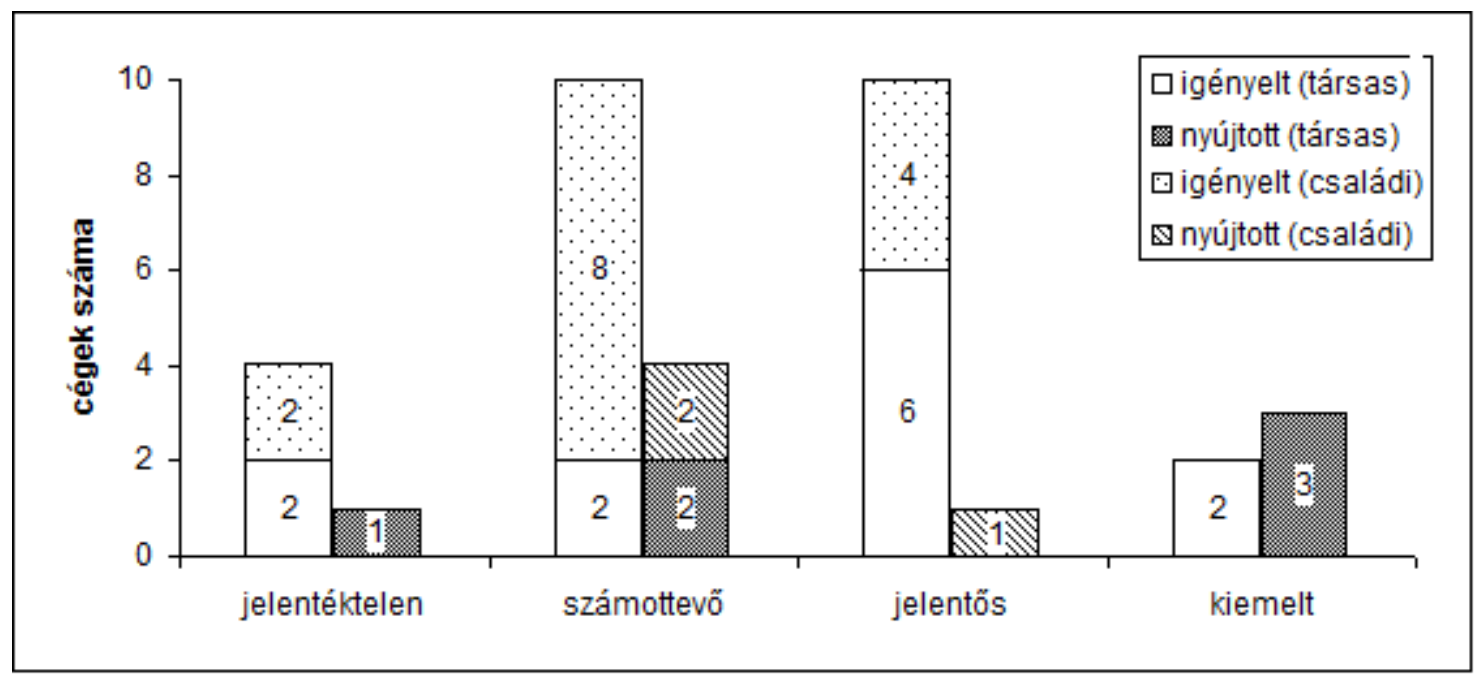

3. ábra. A jelenlegi szolgáltatások jelentősége a gazdaság egésze szempontjából

Az adatszolgáltatók közül ugyanakkor csak 9 (25\%) gazdaság nyújt gépfenntartási szolgáltatásokat másoknak, a társas vállalkozások 37,5\%-a (6 db), míg az egyéni gazdálkodók mindössze $15 \%$-a (3 db). Az elöbbi több mint 50\%-os emelkedés egy évtized alatt, az utóbbi pedig több mint ötszörös, hiszen akkoriban a családi gazdaságok csak alig 3\%-a folytatott ilyen jellegü tevékenységet $[15,9,10]$. Az általuk nyújtott szolgáltatásokat harmaduk kiemelten fontosnak, $11,1 \%$-uk jelentősnek, 44,4\%-uk számottevőnek és 11,1\%-uk jelentéktelennek minősítette [18] a vállalkozás egésze szempontjából (3. ábra).

A válaszolóknál az összes foglalkoztatott 11,6\%-át teszik ki a karbantartók és az éves karbantartási költség a teljes eszközérték 6,2\%-a (a társaságoknál 4,1\%-a, a magántermelöknél 9,6\%-a, tehát több mint kétszerese).

\subsection{A fenntartás egészének vizsgálata}

A vizsgált gazdaságok 11,1\%-ánál csak hibaelhárítás müködik (a 2004/2005-ös felmérésben ez az érték még 35,5\% volt, azóta tehát harmadára csökkent), 19,5\%-uknál állapotfüggő, 33,3\%uknál vegyes és 36,1\%-ánál ciklikus-periódikus karbantartási rendszert alkalmaznak (ez utóbbi arány 10 évvel korábban 39,5\%-ra adódott $[15,9,10])$.

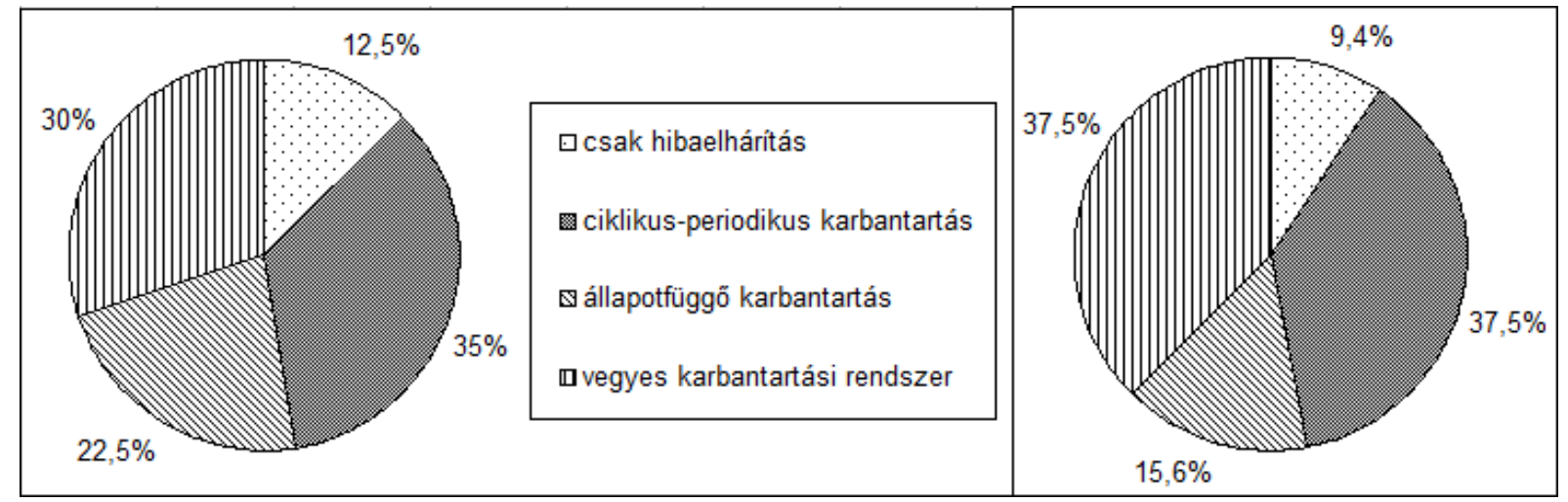

4. ábra. Különbözö karbantartási rendszerek aránya az egyéni (b) és a társas (j) üzemeknél [19]

Örvendetes tény, hogy a 2002-es vizsgálat [1, 13] 12\%-ával ellentétben most egy mezőgazdasági vállalkozás sem vallotta, hogy ne lenne karbantartási rendszere. A különböző gépfenntartás rendszerek arányát vizsgálva lényeges eltérés nem tapasztalható az egyéni és társas gazdaságok között (4. ábra). Egyedül az állapotfüggő karbantartási rendszer családi gazdaságok körében mért közel 7\%-ponttal nagyobb értéke meglepő, de (60\%-uknál) diagnosztikai berendezések nélkül ez nyilvánvalóan téves adatszolgáltatásra utal [19]. Jóllehet 
létezik műszerezettség nélküli, érzékszervi úton történő müszaki diagnosztika. A vizsgálatok elvégzésére és azokból helyes következtetések levonására azonban nagy gyakorlati tapasztalat szükséges [6,11].

Egyébként is kijelenthetö, hogy a diagnosztikai eszközök ellátottsága igen rossz [19]. Tízböl hat mezőgazdasági üzemben nincs diagnosztikai berendezés (bár egy évtizeddel korábban ez az arány még $81,7 \%$ volt, több mint $20 \%$-ponttal magasabb) és $77,8 \%$-uknál nincs diagnosztikai mühely (régebben 98,5\%-ban nem volt [15, 9, 10], tehát ebben is jelentős elörelépés mutatkozik).

Karbantartási szolgáltatást valamilyen módon a mezőgazdasági vállalkozások (közel háromnegyede) 72,2\%-a vesz igénybe. Általában azért, mert kötelező (35,5\%), nem elegendő a szakmai felkészültségük $(38,7 \%)$, nincs eszköz $(16,2 \%)$, gazdaságosabb $(3,2 \%)$, egyéb (kapcsolat) (3,2\%), illetve nincs kapacitásuk (3,2\%). A fent nevezett okok közül kettő aránya lényegesen eltér az évezred elején megállapított értékektől $[15,9,10]$ : a saját kapacitás hiánya 16,6\%-ponttal alacsonyabb [16], ugyanakkor a szakmai felkészültség hiánya 16,2\%-ponttal magasabb lett.

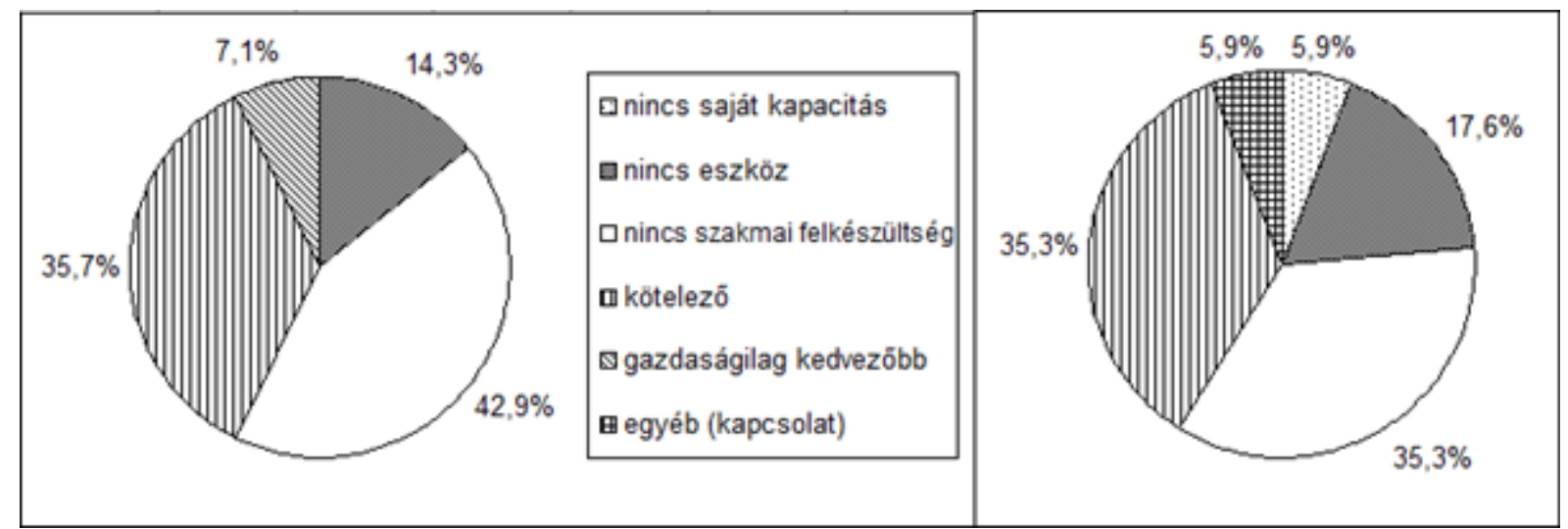

5. ábra. Az igényelt szolgáltatások okainak megoszlása az egyéni (b) és a társas (j) üzemeknél

A családi gazdaságok 7,6 és 7,1\%-ponttal magasabb arányban igényelnek külső szolgáltatást ismerethiány és gazdaságosság okán (ez utóbbi nem is fordult elö a társas vállalkozásoknál indoklásként), míg kapacitáshiány és egyéb okból egyáltalán nem vesznek igénybe fenntartási szolgáltatást szemben a társaságok 5,9-5,9\%-os ilyen jellegü válaszaival (5. ábra).

Az igényelt szolgáltatások 23,8\%-a speciális javításokra, 20,6\%-a garanciális mủveletre, 12,7\%-a nagyjavításokra, 11,1-11,1\%-a múszaki diagnosztikára és váratlan hibaelhárításra, 4,8\%a karbantartási rendszer kialakítására, 9,5\%-a beüzemelésre, valamint 6,3\%-a müszaki elökészítésre, tervezésre irányul [18]. Ez utóbbi két szakterület értéke 7, illetve 6,3\%-ponttal magasabb a 2004-es kutatás eredményénél $[15,9,10]$, míg a váratlan hibaelhárításé $7 \%$-ponttal alacsonyabb.

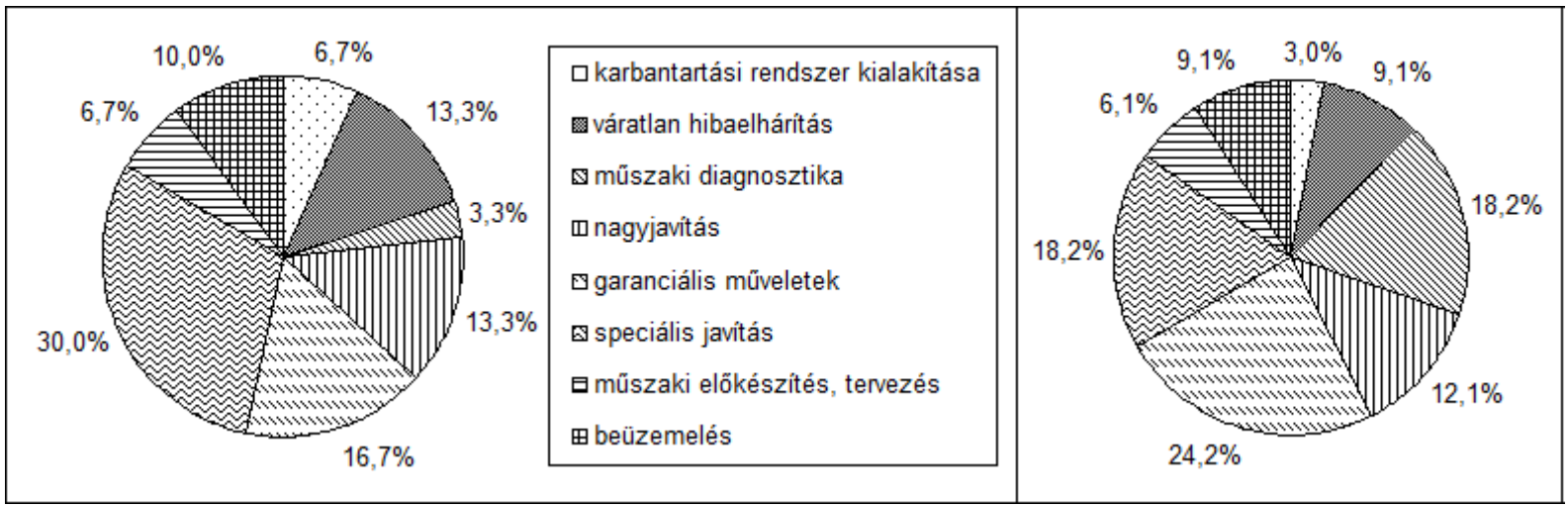

6. ábra. Az igénybevett gépfenntartási szolgáltatások szakterületeinek aránya az egyéni (b) és a társas (j) üzemeknél 
A családi vállalkozások müszaki diagnosztika területen igényelt szolgáltatásainak aránya lényegesen (közel 15\%-ponttal), míg a garanciális műveleteké 7,5\%-ponttal elmarad a társas üzemekétől (6. ábra), ugyanakkor speciális javítások esetén a külső szolgáltató igénybevételének aránya közel 12\%-ponttal nagyobb. Az igénybevett szolgáltatások értéke átlagosan az összes

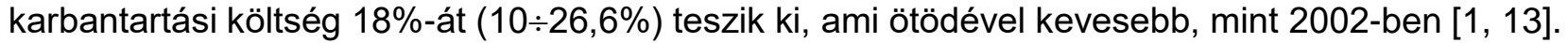

A kérdőívet kitöltők 25\%-a (mindössze negyede, de ez is több mint $11 \%$-ponttal magasabb, mint tíz évvel korábban [15, 9, 10]) nyújt csak szolgáltatásokat föként a tartós partneri kapcsolat miatt (50\%), illetve kijelölt szolgáltatóként (25\%), és csupán 8,3-8,3\%-ban gazdasági okokból, speciális szakismeret hasznosítása, továbbá kapacitáskihasználás céljából. A nyújtott szolgáltatások 27,7\%-a váratlan hibaelhárítás, 13,8-13,8\%-a speciális javítás, valamint müszaki előkészítés, tervezés, 10,3-10,3\%-a nagyjavítás, beüzemelés és garanciális javítás, 6,9-6,9\%-a pedig müszaki diagnosztika és karbantartási rendszer kialakítása (7. ábra).

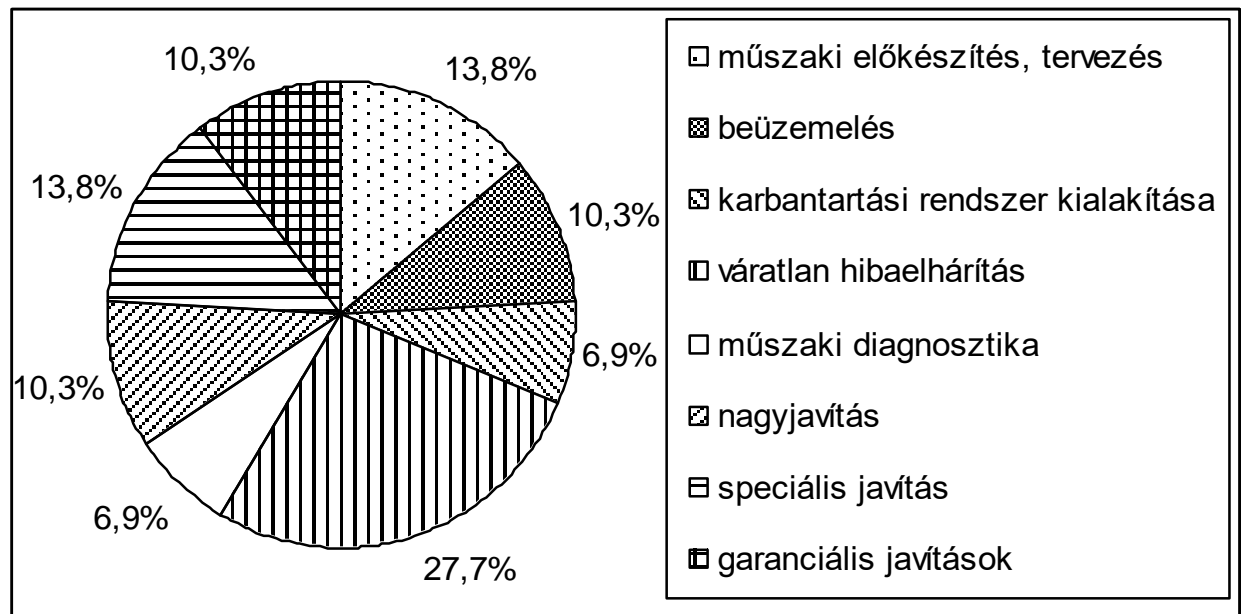

7. ábra. A mezőgazdasági üzemek által nyújtott szolgáltatások szakterületeinek megoszlása

A gépfenntartási tevékenységekbe a vállalkozások $82,9 \%$-a bevonja a gépkezelöket is. Saját karbantartó szervezet - ami a 2000-es évek elején $23 \%$ volt $[9,10,15]$ - napjainkban a gazdaságok 37,1\%-ánál van (kivétel nélkül mind társas vállalkozás; a nagy gépparkkal rendelkező vállalatok esetében egyébként is jellemző a saját gépfenntartó üzem kiépítése [3]), akik átlagosan 20 főt meghaladó karbantartó létszámot foglalkoztatnak. A válaszolók 54,3\%-ánál külső szolgáltató is közremüködik. A karbantartási munkákat 56,2\%-ban (egy évtizeddel korábban $53,6 \%$ adódott $[15,9,10]$ ) a gépkezelök végzik (a termelöüzemi saját gépfenntartás jellegzetes szervezési formája, amikor a gép kezelője végez el bizonyos gépjavítási tevékenységet [3]), a feladatok 17,6\%-át saját szervezet látja el, míg 19\%-át külső eseti szolgáltatásként, 7,2\%-át pedig rendszeres (szerződéses) szolgáltatásként bonyolítják.

A géptárolás feladatait (hasonlóan az évezred első éveihez [8]) döntően (87\%-ban) a gépkezelök végzik maguk vagy az udvarossal, karbantartókkal közösen [5]. Korrózióvédelem, ahogy 2004-ben [14, 15, 9, 10], úgy most is - egy gazdaság kivételével - minden üzemeltetőnél saját eszközzel és dolgozóval történik, közülük egy mezőgazdasági cég vallotta, hogy külső szolgáltatót is alkalmaz erre a feladatra.

A 9 fenntartási szolgáltatásokat is nyújtó vállalkozásból 5 (55,6\%) jelezte (4 társas és 1 családi), hogy bevezeti, illetve bővíti az általuk végzett külső szolgáltatások megrendelőinek elégedettség-vizsgálatát.

\subsection{A cégek elképzelései a szolgáltatások bővítésére}

Öt (13,9\%) gazdaság (3 társas és 2 egyéni) kívánja csak a nyújtott szolgáltatásait növelni vagy bevezetni más cégek számára (a korábbi felmérésben $15 \%$ vallott így $[14,15,9,10]), 1$ nem nyilatkozott, míg a többi 30 egyértelmü nemmel válaszolt, utóbbi okai: a kapacitáshiány (35\%), nincs rá igény $(25 \%)$, más területen bővít $(25 \%)$, gazdaságtalan $(10 \%)$ és a tökehiány $(5 \%)$. A bővítés szakterületei megoszlóak: legnagyobb arányban a müszaki előkészítés, tervezés $(27,3 \%)$, a beüzemelés $(18,2 \%)$ és a javítás $(18,2 \%)$ szerepel, a hibaelhárítás, a műszaki diagnosztika, a 
garanciális ellátás és a logisztikai szakterület egyformán 9,1-9,1\%-ban fordul elö. A bővítés indokai között az árbevételnövelés (37,5\%), a piaci részarány bővítése (25\%), kapacitáshasznosítás $(12,5 \%)$, többletszolgáltatás-nyújtás (12,5\%) és egyéb (segítségnyújtás) (12,5\%) jelenik meg.

Tizenhárom (10 társas és 3 egyéni) vállalkozás $(36,1 \%$, ami közel kétszerese az egykori $20 \%$-os értéknek $[14,15,9,10])$ válaszolta csak, hogy tervezi az igénybevett szolgáltatásait növelni, ugyanennyi (4 társaság és 9 családi vállalkozó) vallotta, hogy nem szeretné, míg 10 nem nyilatkozott, 62,5\%-uk (a cégek 90\%-a, a kistermelök 16,7\%-a) pedig új ajánlatokkal is meg kíván ismerkedni. A nyilatkozók mindegyike elégedett (25\%-a teljes mértékben, $75 \%$-a többnyire) a kínált szolgáltatásokkal. Az igényelt szolgáltatás-bővülés oka 46,1\%-ban a gazdasági előnyökben, 38,5\%-ban saját szakmai felkészültség pótlásában, míg 15,4\%-ban a kapacitáshiányban keresendő. A bővítés területei a következők: müszaki diagnosztika $(28,6 \%)$, javítás $(17,8 \%)$, garanciális ellátás $(14,3 \%)$, hibaelhárítás $(14,3 \%)$, müszaki előkészítés, tervezés $(14,3 \%)$ és beüzemelés $(10,7 \%)$ (8. ábra).

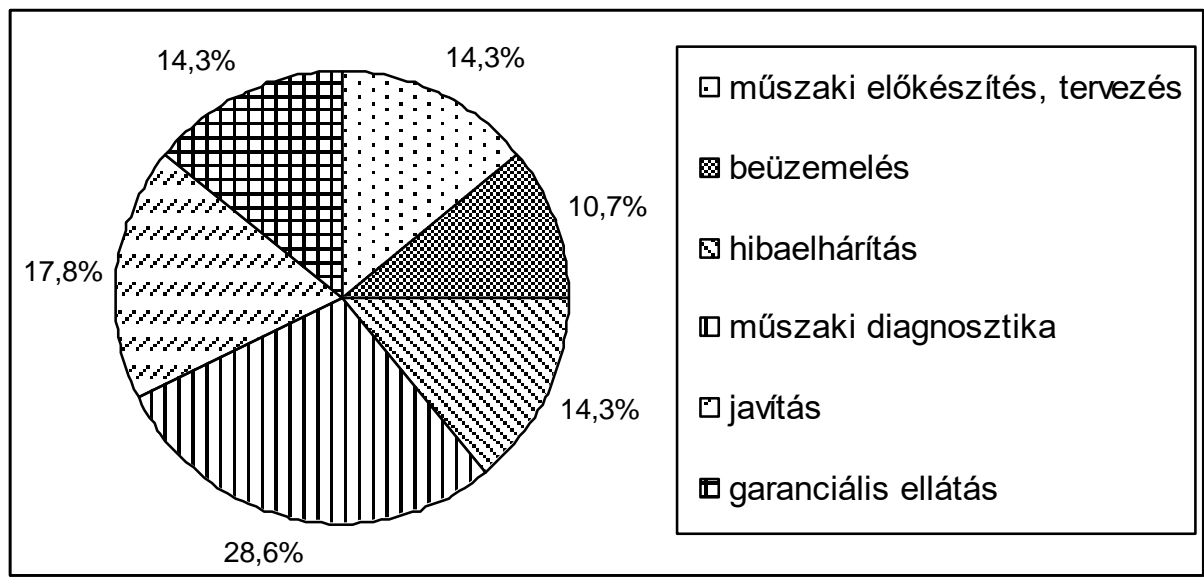

8. ábra. Az igénybevett gépfenntartási szolgáltatásbővités szakterületeinek aránya

\section{Következtetések}

Az elvégzett felmérés tapasztalataiból és értékeléséből néhány következtetés levonható:

- Az egyéni gazdálkodók szinte mindegyike, de még a kis-, és közepes méretü üzemek egy része sem rendelkezik a fenntartás teljes körü elvégzéséhez szükséges feltételekkel, ennek megfelelően csak az ápolási, gondozási feladatcsoportba tartozó munkákat tudják elvégezni [19].

- Mindezek ellenére a karbantartási feladatokat a gazdaságok föként saját kapacitással végzik, több mint felénél külső rendszeres vagy eseti szolgáltatással kiegészítve, ez néhány fő (10 alatti) karbantartó létszámot jelent, de a nagyobb területen gazdálkodók esetében és a jelentős állattartással rendelkező cégeknél nagyobb $(\sim 16,4$ fö) karbantartó létszámot foglalkoztatnak.

- Az alkalmazott karbantartási rendszer döntően ciklikus-periodikus, mégis a fenntartási munkák ütemezésére nem elég kiterjedten használnak teljesítmény-mutatókat [19], pedig az időorientált karbantartási stratégia esetében alapkérdés, hogy az egyes intézkedések ütemezése milyen paraméter alapján történjen.

- Többen ugyan állapotfüggő karbantartási rendszert vallanak, de gyanítható, hogy ez nem általános, hiszen a mezőgazdasági üzemek saját diagnosztikai eszközökkel nem, vagy alig rendelkeznek. Így rendszeres műszeres állapot-figyelés gyakorlatilag ezekben a szervezetekben nincs, ami megegyezik egy korábbi vitaanyag [17] megállapításaival.

- A vizsgált gazdaságok közül 26 (72,2\%) vesz igénybe külső cégtől fenntartási szolgáltatásokat a kötelező (garanciális) szolgáltatásokon kívül elsősorban eszköz- illetve ismerethiány okán, közülük $(77 \%)$ minősíti ezt számottevőnek vagy jelentősnek a gazdaság egésze szempontjából.

- Ugyanakkor gépfenntartási szolgáltatásokat mindössze 9 mezőgazdasági cég (25\%) nyújt másoknak, elsősorban partneri kapcsolatok okán, illetve kijelölt szolgáltatóként váratlan 
hibaelhárítás és speciális javítások terén. Ezt a szolgáltatást egyikük jelentéktelennek minősíti.

- Úgy tünik, hogy mind az igénybevett, mind a nyújtott szolgáltatások terén inkább a kényszerek (elöírások, hiányok) müködnek, és csak kis mértékben a minőség, a gazdaságosság a motiváló tényezö, nem érvényesülnek piaci szempontok [12].

- Figyelemre méltó, hogy a vizsgált társaságok több mint fele sem a nyújtott, sem az igénybevett szolgáltatását nem tervezi bővíteni.

\section{Irodalomjegyzék}

[1] Györki J. et al.: The situation of maintenances services - beginning results of an investigation. $8^{\text {th }}$ International Scientific Symposium, Quality and Reliability of Machines, Nitra, 2003. pp. 200-203.

[2] Janik J. (szerk.): Gépüzemfenntartás I. Dunaújvárosi Főiskola, Főiskolai Kiadó Dunaújváros, 2001. 7. o.

[3] Janik J. (szerk.): Gépüzemfenntartás II. Dunaújvárosi Főiskola, Főiskolai Kiadó Dunaújváros, 2009. 709. o.

[4] Oláh B.: A gépfenntartás jelenlegi helyzetének felmérése a mezőgazdaságban. XXI. Nemzetközi Környezetvédelmi és Vidékfejlesztési Diákkonferencia, In: ECONOMICA, A Szolnoki Főiskola Tudományos Közleményei VIII. új évfolyam 3. szám. Szolnok, 2015. pp. 258-265.

[5] Oláh B.: A mezőgazdasági gépek tárolásának helyzete napjainkban. IX. Alföldi Tudományos Tájgazdálkodási Napok, A Szolnoki Föiskola Nemzetközi Konferenciája a Magyar Tudomány Ünnepén, In: ECONOMICA, A Szolnoki Főiskola Tudományos Közleményei VIII. új évfolyam 4/1. szám. Szolnok, 2015. pp. 35-44.

[6] Oláh B.: A müszaki diagnosztika végrehajtása.ppt 7. dia, Müszaki diagnosztika előadás, Szolnoki Főiskola, Szolnok, 2016.

[7] Szücs S., Vermes P.: A karbantartás kiszervezése - elvek, lehetőségek, megoldások. Müszaki Tudomány az Észak-kelet Magyarországi Régióban, Szolnok, 2012. In: Elektronikus Műszaki Füzetek 11. (szerk.: Pokorádi L.) Debrecen, 2012. pp. 115-130.

[8] Vas F., Vermes P.: Tárolják, vagy félreállítják? Gondolatok a mezőgazdasági gépek tárolásáról. MTA-AMB XXX. K+F Tanácskozás, Gödöllö, 2006. pp. 175-180.

[9] Vas F., Vermes P.: Szerviz és gépjavítás létesítményei (a tervezés szempontjai kis és közepes méretű mezőgazdasági üzemekben). Gépfenntartási segédlet. SZF Müszaki és Mezőgazdasági Fakultás, Mezőtúr, 2006. p. 70 (FVM 43532 sz. K+F téma keretében) Kézirat

[10] Vas F., Vermes P.: Mezőgazdasági üzemek szerviz- illetve gépjavító műhelyeinek tervezési szempontjai. Oktatási és gyakorlati segédlet. FVM Mezőgazdasági Gépesítési Intézet, Gödöllö, 2006. p. 24 (FVM 43532 sz. K+F téma keretében) Kézirat

[11] Vermes P., Herbály L., Vas F.: Üzemfenntartás. GATE MFK Mezőtúr, főiskolai jegyzet. 1996. p. 111.

[12] Vermes P.: A karbantartási szolgáltatások piaci szempontjai. MTA-AMB K+F Tanácskozás. Gödöllő, 2002. 3. köt. pp. 152-156.

[13] Vermes P. et al.: A karbantartási szolgáltatások helyzete - egy felmérés kezdeti eredményei. MTA-AMB Kutatási és Fejlesztési Tanácskozás, Gödöllö, 2003. pp. 248-252.

[14] Vermes P. (összeáll.): Részjelentés „A mezőgazdasági gépüzemfenntartás fejlesztése, a gépek optimális üzemben tartásának meghatározása" címü kutatási témához. Mezőtúr, TSF MFK, 2004. p. 16 + mell.

[15] Vermes P., Vas F.: A gépkarbantartás helyzete és megoldások a mezőgazdaságban. Műszaki Tudomány az Észak-Alföldi Régióban, Nyíregyháza, 2006. In: Elektronikus Müszaki Füzetek II., (szerk.: Pokorádi L., Kalmár F.) Debrecen, 2006. pp. 5-22.

[16] Oláh B.: Managing maintenance services in agriculture in eastern Hungary. Fórum Manažéra, Trnava, Slovakia, 12. évf., 1. szám, 2016. pp. 42-47. (https://www.forummanazera.sk/archiv/2016 Forum\%20Manazera\%201 online.pdf)

[17] Janik J. et al.: A mezőgazdasági gépek üzemfenntartásának időszerű kérdései. MTA-AMB K+F Tanácskozás, Gödöllö, 2003. p. $11+3$ mell.

[18] Oláh B.: The situation of maintenance services in agriculture. In: Proceedings of the $4^{\text {th }}$ International Scientific Conference on Advances in Mechanical Engineering (ISCAME 2016), University of Debrecen, Faculty of Engineering, Edited by S. Bodzás, T. Mankovits, 13-15 October, 2016. Debrecen, pp. 382-388.

[19] Oláh B.: Saját fenntartási tevékenység helyzete a mezőgazdaságban. AGTEDU 2017, A Neumann János Egyetem 17. Tudományos Konferenciája a Magyar Tudomány Ünnepe Alkalmából, Szolnok, In: GRADUS, Vol 4, No 22017. autumn (november), pp. 118-128. (http://gradus.kefo.hu/archive/2017-2/2017 AGR 005 Olah.pdf)

[20] Szendrő P. (szerk.): Géptan. Mezőgazda Kiadó, Budapest, 2003. p. 810 